\title{
Does it pay more to be green in family firms than in non-family firms?
}

\section{Concepción Garcés-Ayerbe ${ }^{1}$ (D) $\cdot$ Pilar Rivera-Torres $^{1}$ (D) Josefina L. Murillo-Luna ${ }^{1}$ (D) . Cristina Suárez-Gálvez ${ }^{2} \mathbb{D}$}

Received: 11 June 2020 / Accepted: 18 May 2021 / Published online: 14 July 2021

(c) The Author(s) 2021

\begin{abstract}
The contradictory empirical evidence about whether the effect of companies' environmental investments on financial results is positive, negative or not significant has been explained by the different conditions and contexts that facilitate or hinder the ability to generate a win-win situation. This explanation has gradually led the academic debate to consider the factors and conditions that moderate such a relationship. In this document, we analyse the relevant but scarcely studied moderating effect of the condition of being a family firm, by integrating the socioemotional wealth (SEW) perspective into the natural-resource-based view (NRBV). Based on the analysis of panel data from 2936 Spanish manufacturing firms, covering the period 2009-2016, we offer empirical evidence showing that the financial benefits derived from environmental investment are positive and significant in family firms, while this is not so in non-family firms. Furthermore, our results show that intrinsic characteristics such as the sector, size or age of the company also condition the financial results of environmental investments.
\end{abstract}

Keywords Environmental investment - Financial performance $\cdot$ Win-win situation · Ownership structure $\cdot$ Family firm $\cdot$ Moderating effect

Concepción Garcés-Ayerbe

cgarces@unizar.es

Pilar Rivera-Torres

privera@unizar.es

Josefina L. Murillo-Luna

jmurillo@unizar.es

Cristina Suárez-Gálvez

cristina.suarez@uah.es

1 Institute on Employment, Digital Society and Sustainability (IEDIS), University of Zaragoza, C/Gran Vía, 2, 50006 Zaragoza, Spain

2 Faculty of Economic and Business Sicences, University of Alcalá, Pza. San Diego, s/n, 28801 Alcalá de Henares (MADRID), Spain 
JEL Classification M19 · D22 · C23

Mathematics Subject Classification 62J05 · Linear regression; mixed models

\section{Introduction}

The growing concern for the natural environment over the last few decades is promoting green entrepreneurship and forcing companies to move away from the traditional narrow short-term approach, which limited their focus to their own financial objectives, and to broaden their interests to try to reduce the environmental impact of their activity (Melay and Kraus 2012; Endrikat et al. 2014; Li et al. 2017). In this context, Trumpp and Guenther (2017: 3) defined the concept of environmental performance as the "results of an organization's management of its environmental aspects", which is added to the corporate financial performance concept of "economic outcomes resulting from the interplay among an organization's attributes, actions, and environment", in order to set more ambitious corporate sustainability goals (Alshehhi et al. 2018). Whether for external legitimacy or competitive advantage, companies seek to achieve win-win situations in which, at the same time, the adoption of environmental protection practices contributes to improving their financial performance (Miroshnychenko et al. 2017; Lucato et al. 2017; Song et al. 2017).

One aspect that might be a facilitator of the desired win-win situation is the condition of being a family firm. According to the socioemotional wealth (SEW) perspective, family firms (in which the owning family takes care of the ownership and control of the firm with a desire for generational continuity) have distinctive characteristics such as long-term vision and accumulation of intangible values, such as reputation or the generation of trust in stakeholder relationships (Neubaum et al. 2012). These characteristics explain why environmental performance is of particular relevance for family businesses, where success is measured not solely in terms of economic performance (Gómez-Mejía et al. 2007). They can also be expected to influence the selection, implementation and development of environmental projects and lead them not only to improve environmental outcomes but also to improve financial performance. Nevertheless, the effect of the type of firm governance on the relationship between environmental and financial performance has scarcely been explored. In fact, we have found only two studies-Craig and Dibrell (2006) and Huang et al. (2014) — which explain that these distinctive characteristics of family firms favour the possibility of environmental investments translating into improved financial results, thus showing that the effectiveness of environmental proactivity for the firm's financial results is greater in family firms than in non-family firms.

The relationship between firms' environmental and economic performance has been widely studied in the management literature since the 1980s. Nevertheless, the debate about the sign of this relationship remains open (Endrikat et al. 2014; Yu and Zhao 2015; Trumpp and Guenther 2017; Alshehhi et al. 2018; Cañón-de-Francia and Garcés-Ayerbe 2019). Recent empirical research has yielded results that seem contradictory, since some claim that the economic effects of environmental effort 
are positive (Kushwaha and Sharma 2016; Testa et al. 2018), while others suggest that they are negative (Li et al. 2017) or not significant (Lucato et al. 2017).

Some authors have attempted to investigate the reasons for this lack of consensus and claim that this relationship is not as obvious as it seems, because it is conditioned by numerous external and internal factors that affect its sign and intensity (Menguc and Ozanne 2005; Endrikat et al. 2014; Garcés-Ayerbe and Cañón-de-Francia 2017). There is a vast amount of theoretical and empirical evidence in the environmental management literature to support this argument. In a non-exhaustive enumeration, two types of factors have been highlighted in the literature among many others as moderators or mediators of the economic effects of the environmental effort. One of them refers to internal factors, such as capability for innovation (Christmann 2000), the proactive/reactive nature of the strategic approach (Endrikat et al. 2014), the organizational design (Rivera-Torres et al. 2015) or corporate governance characteristics (Pekovic and Vogt 2020). The other type are external conditions, such as the uncertainty, complexity and munificence of the general business environment (Aragón-Correa and Sharma 2003), the strictness of environmental requirements (Filbeck and Gorman 2004), customers' sensitivity to environmental issues (Menguc and Ozanne 2005), the extent to which the type of industry generates pollution (Lucas and Noordwier 2016) or the external economic situation (Cañón-de-Francia and Garcés-Ayerbe 2019).

Hence, the academic debate on the question "Does it pay to be green?" (first posed by Hart and Ahuja in 1996) is now being redirected towards the question "When does it pay to be green?" (Orsato 2006; Ambec and Lanoie 2008; Dixon-Fowler et al. 2013; Ghisetti and Rennings 2014), highlighting the need to consider moderating variables that could affect the relationship between environmental and financial performance (Grewatsch and Kleindienst 2015).

Grewatsch and Kleindienst (2015) pointed out that ownership structure represents one of the most powerful forces affecting firm strategy and performance. However, hardly any studies have been conducted on the effect of the type of firm governance on the relationship between environmental and financial performance. These authors therefore propose the consideration of different types of owners (family versus nonfamily) as a possible internal moderating variable in this relationship. Their proposal could be translated into a more specific question: "Does it pay to be green in family firms more than in non-family firms?". Thus, the aim of this study is to contribute to the debate about the variables that can moderate the effect of environmental investments on firms' financial performance. Specifically, we integrate the SEW perspective into natural-resource-based view (NRBV) so as to be able to consider the possible moderating effect of the family (or non-family) nature of the firm. From a methodological perspective, one of the distinctive elements of this research lies in the application of the panel data methodology to a representative sample of Spanish manufacturing firms, which allows us to control for different omitted effects that vary across firms and are not introduced as control variables. 


\section{Theoretical framework}

\subsection{Relationship between environmental and financial performance}

Thirty years ago, the so-called Porter hypothesis maintained that strategic environmental innovation decisions could give rise to win-win situations, with beneficial effects for firms' economic competitiveness (Porter 1991). Since then, different authors have put forward several arguments to explain the positive relationship between environmental investment and profitability. The arguments that have garnered the most support are cost reduction and improvement of operational efficiency derived from better use of resources (Porter and van der Linde 1995; Grekova et al. 2013), greater productivity resulting from renewing outdated production equipment with more modern replacements (Xepapadeas and Zeeuw 1999), greater product and service quality as a result of eco-design and green entrepreneurship (Melay and Kraus 2012; Kushwaha and Sharma 2016; Iranmanesh et al. 2019), increased product attractiveness and differentiation (Klassen and McLaughlin 1996; Rivera-Torres et al. 2015), external legitimacy (Testa et al. 2018), inter-organizational learning derived from collaboration with other stakeholders in the supply chain (Vachon and Klassen 2008), better stakeholder relations (Brekke and Nyborg 2008; Bénabou and Tirole 2010) or improvement of future position and long-term growth (Hart and Dowell 2011).

These arguments have been supported from the NRBV, proposed by Hart (1995) as an extension of the resource-based view (Barney 1991; Dierickx and Cool 1989; Rumelt 1984). According to the NRBV, a firm can obtain sustainable competitive advantages from key capabilities and resources for the environmental sustainability of its economic activity. Hart's (1995) proposal considered three interrelated capabilities (pollution prevention, product management and sustainable development) that can represent a source of competitive advantages via cost reduction, anticipation of competitors and better stakeholder relations. After Hart's (1995) first contribution, other authors also followed this line of research, with a natural resource-based approach (Russo and Fouts 1997; Sharma and Vredenburg 1998; Hart and Milstein 2003; Menguc and Ozanne 2005; Hart and Dowell 2011). They all defended the positive link between environmental and financial performance, because of the availability of strategic resources and capacities, such as continuous improvement, stakeholder management, physical assets and technology, organizational culture, inter-functional coordination, and other intangible resources, in addition to attracting and retaining quality employees, reducing costs and increasing operational efficiency (Ramanathan 2018).

These contributions have provided support for the Porter hypothesis, which represented an important change, as it questioned the predominant argument in the 1980s that claimed that there was a trade-off between environmental investment and financial performance, with significant harm to a firm's competitiveness (Walley and Whitehead 1994; Jaffe et al. 1995; Preston and O'Bannon 1997).

Nonetheless, the debate on the relationship between environmental and economic performance remains open, since there exist other studies which do not 
support the Porter hypothesis and argue that the relationship between environmental investment and financial performance is negative or not significant (Gilley et al. 2000; Sarkis and Cordeiro 2001; Bansal 2005; Sueyoshi and Goto 2010; Venkatraman and Nayak 2015; Lucato et al. 2017; Li et al. 2017). Venkatraman and Nayak (2015) explained these results by means of the difficulties in achieving distinctive competitive advantages using certain environmental investments (such as the implementation of an Environmental Management System), given that such practices are becoming widespread among all competitors. On the other hand, even if companies develop technologies to reduce their environmental impact, these can bring them competitive advantages for a limited time, until competitors imitate them and catch up with them. Li et al. (2017), instead, suggested that the impact is not immediate and it may take more than a year for companies to observe it.

Despite the lack of consensus regarding the impact of environmental activities on financial performance (Aragón-Correa et al. 2008; González-Benito and GonzálezBenito 2005; Molina-Azorín et al. 2009), in this study the NRBV is taken as a basis to propose the following hypothesis related to the impact of environmental investment on financial performance, and then perform a subsequent broader analysis.

H1 The financial benefits derived from environmental investment are positive.

However, authors such as Endrikat et al. (2014) or Garcés-Ayerbe and Cañónde-Francia (2017) note that financial benefits derived from environmental investment can be positive when environmental strategies are adequately designed and internal-external conditions are not unfavorable. Therefore, these authors insisted on the relevance of incorporating moderating variables in the study of this relationship. This leads us to go into the analysis in greater depth, in an attempt to find out whether the positive relationship between environmental investment and financial results could only occur under certain circumstances.

\subsection{Family firms and the relationship between environmental and financial performance: background}

There is no solid consensus regarding the definition of a family firm. This study considers the one proposed by Corona and Telléz-Roca (2011: 795), according to which it is "that in which a family group is in a position to appoint the firm's chief executive officer and establish its business strategy, all aimed at generational continuity, based on the desire of both founders and successors to maintain ownership and keep management in the family".

Although this is a relatively recent line of research, there are already sufficient theoretical arguments and empirical evidence to state that the type of ownership of firms (family or non-family) is a variable that explains the differences between firms in environmental matters (Craig and Dibrell 2006; Huang et al. 2009).

Previous literature has focused on analyzing whether family firm status determines the environmental proactivity of firms. Berrone et al. (2010), for instance, 
maintained that family firms adopt proactive environmental strategies more often than non-family firms in polluting industries. There are several reasons that explain why family firms are especially interested in integrating the environmental variable. If this were not the case, they could well be identified as irresponsible by society. A negative image or poor reputation derived from failing to respect the environment could have serious consequences for the firm (Berrone et al. 2013). Family firms are thus more sensitive to external stakeholders' (environment, community and clients) demands and have stronger links with their closest communities (Sageder et al. 2018). Uhlaner et al. (2004) recognized a special or different relationship between family firms and their clients, which favors the use of environmental management systems to meet their demands. Huang et al. (2009) maintained that the relationship between internal stakeholder pressure and the use of environmental innovations is more intense in family firms.

Despite the large number of studies that consider the condition of being a family firm as a determining factor of strategic environmental behavior, only a few-such as Craig and Dibrell (2006) and Huang et al. (2014) — have analyzed its possible moderating effect on the relationship between environmental investment and financial results. Based on the SEW perspective, in this paper we argue that the condition of being a family firm represents a factor that favors the possibility of achieving a win-win situation through investments in environmental protection, which is a position in which both environmental and financial results are improved.

The SEW perspective refers to "non-financial aspects of the firm that meet the family's affective needs, such as identity, the ability to exercise family influence, and the perpetuity of the family dynasty" (Gómez-Mejía et al. 2007: 106). From this perspective, there are arguments in the literature about the distinctive features of family firms, such as their concern for the protection and perpetuation of the family reputation, their vision and long-term commitment or the greater involvement and loyalty of their employees (Neubaum et al. 2012), which suggest that the economic effects of environmental strategies could be greater in this kind of firms. These elements represent a favorable situation for an adequate selection of investments in environmental protection, and for an adequate implementation and use of such investments. In this sense, Craig and Dibrell (2006) argued that a long-term approach involves a less risky selection of environmental investments, which favors financial results. Furthermore, according to these authors, the innovation effort associated with environmental policy will be greater in family firms than in non-family firms, as they will have more flexible decision-making structures and processes, which in turn favour the achievement of competitive advantages that will have a positive impact on financial results. Gast et al. (2018) also verify how certain configurations of the five dimensions of SEW proposed by Gómez-Mejía et al. (2007)—exert influence on the firm, preserve family identity with the firm, preserve binding social ties, maintain emotional attachment, and ensure family succession-lead to higher levels of innovation in small and medium-sized companies.

According to the SEW perspective, success in family firms is not evaluated only on the basis of wealth creation and financial results (Habbershon et al. 2003; Basco 2017), but is also associated with intangible aspects such as values, culture and reputation (Gómez-Mejía et al. 2007). Family firms are especially interested 
in having a good reputation, given the implication and high level of identification of the business with those who own and control the firm (Sharma and Manikutty 2005; Sageder et al. 2018). To protect their socioemotional wealth, family firms try to satisfy the demands of a growing number of stakeholders, who value the name, the family reputation and the contribution that the firms make to the community to which they belong (Zellweger and Nason 2008; Berrone et al. 2010; Debicki et al. 2017). Environmental investments represent an adequate mechanism to improve the firm's reputation (Baah et al. 2020). Thus, the natural environment is part of those intangible aspects determined by values, which family firms have a special interest in protecting, and this represents a source of sustainable competitive advantage for them (Craig and Dibrell 2006; Berrone et al. 2013). In sum, environmental policy in family firms can be expected to be more clearly directed towards improving reputation and generating trust with stakeholders than in non-family firms, thereby giving rise to higher comparative advantages in terms of avoiding conflicts and generating trust, with the consequent improvement in financial results.

Long-term orientation is another distinctive characteristic of family firms (Le Breton-Miller and Miller 2006; Zellweger et al. 2013), which manifests itself as long periods of tenure in senior management, long-term investment horizons and consideration of future generations (Sageder et al. 2018). The time perspective of family firms is transgenerational (Habbershon and Pistrui 2002; Sharma and Irving 2005). In order to preserve the family dynasty in the business and transmit family values to younger generations (Gómez-Mejía et al. 2007), family firm leaders seek the loyalty of their clients and establish long-term relationships with their stakeholders (Zellweger et al. 2013). This could help to reduce the costs of managing strategic alliances (Mohr and Puck 2013), to achieve legitimacy within society and to create long-term successful firms (Debicki et al. 2017; Sageder et al. 2018). Actions and projects aimed at protecting the environment will be chosen and managed in this favorable breeding ground, thus improving the possibility of achieving a win-win situation. Furthermore, environmental investments are often linked to higher initial costs, with potentially greater long-term social and economic benefits, but with longer recovery periods than other investments (Makower 1993). Hence, not only could family firms be more likely to make environmental investments (Hart and Ahuja 1996), but they might also earn better returns than non-family firms (Arregle et al. 2007; Xi et al. 2015).

Finally, another distinctive characteristic of family firms is the greater identification and involvement of their employees with the firm's objectives (Huang et al. 2009). Family businesses are committed to the needs of their employees (Huang et al. 2014), with whom they may even have family ties. This contributes to creating an organizational social climate that positively affects the motivation of the employees, whose interests are aligned with those of the firm (Collins and Smith 2006; Eddleston and Kellermanns 2007). It also favors the acquisition of firm-specific knowledge regarding the firm's internal operating processes (Bruton et al. 2003) and the creation of more efficient and coordinated work teams that maintain fluid communication (Kellermanns et al. 2012; Azoury et al. 2013). Moreover, close relationships with their employees can also help family firms connect with other stakeholders, not only within the organization but also outside it, and establish personal 
networks of long-term relationships to support their demands, thereby achieving competitive advantages over non-family firms (Neubaum et al. 2012). As a result, family firms could achieve greater efficiency in their environmental management activities and in the financial results derived from them (Craig and Dibrell 2006), since investors could perceive this potential powerful intangible resource for family firms, which is not held by non-family firms (Neubaum et al. 2012), and value their environmental investments positively (Huang et al. 2014).

Hence, integrating the SEW perspective into the NRBV, we propose the following hypothesis about the moderating effect of being a family firm on the relationship between environmental investment and economic performance:

H2 The economic performance derived from environmental investment is greater in family than in non-family firms.

\section{Empirical analysis}

\subsection{Description of the sample and relevant variables}

We used a data set of Spanish manufacturing firms from the Survey on Business Strategies (Encuesta sobre Estrategias Empresariales, ESEE) conducted annually by the SEPI Foundation (Fundación SEPI). The ESEE is representative of the Spanish manufacturing firms classified by industry and size (for more details on the survey design see https://www.fundacionsepi.es/investigacion/esee/en/spresentacion. asp). The sample contained firms from 2009 to 2016, and the final database consisted of an unbalanced panel of 13,735 observations corresponding to 2,936 firms. Our hypotheses, then, were tested with a series of historical data. The observations were selected by considering all the firms in the ESEE database for which there was information on all the relevant variables. The series starts in 2009 because only since then have data for one of the key variables, environmental investment, been available.

Given our hypotheses and the information available in the database that was used, the following variables were selected:

Environmental investment: a variable that shows whether the firm made investments in equipment or facilities related to the control of environmental pollution. Environmental investment has been considered an indicator of environmental performance in both classical (Klassen and McLaughlin 1996) and recent literature (Nakamura 2011; Bostian et al. 2016; Garcés-Ayerbe and Cañón-de-Francia 2017). According to the information available in the survey, it is a dummy variable with a value of 1 when the firm makes an environmental investment in the year and 0 otherwise.

Family versus non-family firm: a variable that shows whether a family group is actively involved in the firm's control or management. This indicator of family firms has previously been used in the literature by authors such as López-Cozar Navarro et al. (2013, 2016), Ramírez-Alesón and Fernández-Olmos (2019) or Ramírez et al. 
(2020). According to the information available in the survey, it is a dummy variable with a value of 1 when the firm is a family enterprise and 0 otherwise.

Return on investment (ROA): a variable that shows the return on the capital invested in the asset. It is the profit ratio before interest and taxes divided by the total asset, with an approximate value based on the information available in the ESEE. We used this variable as a proxy for the firm's financial performance based on previous studies in the area of environmental performance research (Watson et al. 2004; Nakao et al. 2007; Aguilera-Caracuel and Ortiz-de-Mandojana 2013; Albertini 2013; Dixon-Fowler et al. 2013).

Activity/Sector: we considered sectorial control variables representing the firm's main activity, following the CNAE-09 3-digit codes, and identified 20 manufacturing sectors, as shown in Table 1.

Time period: a variable showing the year in question. Given that the period considered includes a major recession in Spain affecting the year 2008, this is important.

Size: a control variable considering three categories, to distinguish between small (less than 50 workers), medium (50 to 249 workers) and large (250 or more workers) firms.

Experience/Age: a control variable considering three categories, to distinguish between young (less than 15 years), mature (15 to 29 years) and old (30 or more years) firms.

Table 1 shows the distribution of the sample observations according to the relevant variables used in the paper. According to the data in Table 1, 44.31\% of the 13,735 observations are family firms and the remaining $55.69 \%$ are non-family enterprises. Nearly $50 \%$ of the firms in the sample have fewer than 50 workers and medium-sized and large firms represent $34.36 \%$ and $15.25 \%$ of the sample, respectively. Most firms are mature and old firms, with $42.50 \%$ and $43.08 \%$ of the total, respectively. Yet only $23.68 \%$ of all the firms make environmental investments. Regarding the sectors involved, the largest proportion corresponds to Fabricated metal products, $12.84 \%$, followed by Food and tobacco, with $11.87 \%$.

\subsection{Methodology}

In order to test our hypotheses, we first analyzed the distribution of the observations of the sample, and their distribution according to relevant pairs of variables. At the same time, mean return on investment values were analyzed by variable category. This was followed by an estimation of three structural models, the model being estimated in three different samples: the full sample, the sub-sample of family firms and the sub-sample of non-family firms.

In this paper, we have used a panel data set. Accordingly, we chose to use fixed effect or random effect to analyze the relationship between variables:

$$
R O A_{i t}=h\left(x_{i t} ; \theta\right)+c_{i}+\varepsilon_{i t}
$$

where $R O A_{i t}$ is the return on assets in the $\mathrm{i}$-th firm and t-th period. $h\left(x_{i t} ; \theta\right)$ is a function of variables that denote firm characteristics and structural change, whilst $\theta$ is a vector of the parameters to be estimated. The variable $c_{i}$ is the unobservable 
Table 1 Distribution of the sample
Sample distribution

N

$\%$

Family owned

Yes

6086

44.31

No

7649

55.69

Environmental investment

Yes

3253

23.68

No

10,482

76.32

Size

Small (less than 50)

6921

50.39

Medium (50 to 249)

4719

34.36

Large (250 or more)

2095

15.25

Age/experience

Young (less than 15)

1981

14.42

Mature (15 to 29)

5837

Old (30 or more)

5917

42.50

Temporal variable

2009

1917

13.96

2010

1916

13.95

2011

1730

12.60

2012

1782

1582

12.97

2013

1443

11.52

2014

10.51

2015

1599

11.64

2016

1766

12.86

Sectorial variable

Meat products

583

4.24

Food and tobacco

1630

11.87

Beverage

313

2.28

Textiles and clothing

846

6.16

Leather, fur and footwear

3.14

Timber

3.28

Paper

451

4.37

Printing (before edition)

Chemicals and pharmaceuticals

Plastic and rubber products

Non-metal mineral products

Basic metal products

Fabricated metal products

Machinery and equipment

Computer prod., electro./ optical

Electric materials and accessories

Vehicles and accessories

Other transport equipment
3.73

7.14

5.65

6.73

3.20

600

980

776

924

12.84

1,764

6.04

830

1.72

236

3.85

648

4.72

269 
Table 1 (continued)

\begin{tabular}{lll}
\hline & \multicolumn{2}{l}{ Sample distribution } \\
& $\mathrm{N}$ & $\%$ \\
\hline Furniture & 625 & 4.55 \\
Other manufacturing & 348 & 2.53 \\
Total & 13,735 & 100 \\
\hline
\end{tabular}

individual specific effect and $\varepsilon_{i t}$ is the random disturbance. Equation [1] was estimated by fixed effects or random effects, taking into account the nature of $c_{i}$, which captures the unobservable individual specific effects. The Hausman test was used to determine the most efficient and consistent model. Under the null hypothesis of the Hausman test, both models were consistent, but the random effects specification was more efficient. The rejection of the null hypothesis suggested that the fixed effects model was more appropriate. We also added two tests to find heteroscedasticity (modified Wald test) and AR(1) type autocorrelation (Wooldridge test). Finally, to test the robustness of our structural models, we progressively included some control variables, such as size, age, sector and time, in the estimations proposed.

\section{Results}

\subsection{Descriptive evidence}

Table 2 shows the distribution of the sample of firms with environmental investment according to relevant variables. Following the percentages of firms making environmental investments in the family and non-family categories, Table 2 shows that the percentage was slightly greater in non-family firms. Thus, $24.56 \%$ of the non-family enterprises invested in environmental protection, while only $22.57 \%$ of the family firms did so, and this difference between family and non-family firms regarding their environmental behavior is significant. It could also, however, be explained by the smaller mean size of the family firms in the sample rather than by less environmental proactivity.

According to the information by size, only $7.69 \%$ of the small firms made environmental investments. There was, however, some bias towards family firms (small family $9.41 \%$ versus small non-family $6.22 \%$ ) when analyzing the investment trend in small companies. In addition, 59.90\% of the large firms invested in environmental protection equipment and facilities, while $31.07 \%$ of the medium-sized firms did so. Unlike in the group of small firms, these percentages fell to $58.08 \% / 30.79 \%$ when referring to family firms and rose to $60.74 \% / 31.32 \%$ in the case of non-family firms. The results enable us to conclude that medium-sized and large family firms are less likely to invest in environmental protection than non-family firms. Regarding the analysis by age, it can be observed that the oldest firms were the ones that performed a greater environmental investment $(30.86 \%)$, followed by the youngest 
Table 2 Proportion of firms with Environmental Investment according to relevant variables

\begin{tabular}{|c|c|c|c|c|c|c|}
\hline & \multicolumn{2}{|c|}{ Total sample } & \multicolumn{4}{|c|}{ Family owned } \\
\hline & $\%$ & Difference test & Yes & Difference test & No & Difference test \\
\hline \multicolumn{7}{|c|}{ Family owned } \\
\hline Yes & $22.57 \%$ & $\chi^{2}(1)=7.42 * * *$ & & & & \\
\hline No & $24.56 \%$ & & & & & \\
\hline \multicolumn{7}{|l|}{ Size } \\
\hline $\begin{array}{c}\text { Small (less } \\
\text { than } 50 \text { ) }\end{array}$ & $7.69 \%$ & $\chi^{2}(2)=2642.81 * * *$ & $9.41 \%$ & $\chi^{2}(2)=874.81^{* * *}$ & $6.22 \%$ & $\chi^{2}(2)=1756.71^{* * *}$ \\
\hline $\begin{array}{l}\text { Medium } \\
\text { (50 to } \\
249)\end{array}$ & $31.07 \%$ & & $30.79 \%$ & & $31.32 \%$ & \\
\hline $\begin{array}{c}\text { Large ( } 250 \\
\text { or more) }\end{array}$ & $59.90 \%$ & & $58.08 \%$ & & $60.74 \%$ & \\
\hline \multicolumn{7}{|l|}{$\begin{array}{l}\text { Agelexperi- } \\
\text { ence }\end{array}$} \\
\hline $\begin{array}{l}\text { Young } \\
\text { (less than } \\
15)\end{array}$ & $20.60 \%$ & $\chi^{2}(2)=304.23 * * *$ & $19.77 \%$ & $\chi^{2}(2)=103.57 * * *$ & $21.04 \%$ & $\chi^{2}(2)=209.64 * * *$ \\
\hline $\begin{array}{c}\text { Mature (15 } \\
\text { to } 29)\end{array}$ & $17.46 \%$ & & $17.03 \%$ & & $17.80 \%$ & \\
\hline $\begin{array}{l}\text { Old ( } 30 \text { or } \\
\text { more) }\end{array}$ & $30.86 \%$ & & $28.42 \%$ & & $33.04 \%$ & \\
\hline $\begin{array}{c}\text { Temporal } \\
\text { variables }\end{array}$ & & $\chi^{2}(7)=10.38$ & & $\chi^{2}(7)=15.59 * *$ & & $\chi^{2}(7)=5.47$ \\
\hline $\begin{array}{l}\text { Sectorial } \\
\text { variables }\end{array}$ & & $\chi^{2}(19)=1067.07 * * *$ & & $\chi^{2}(19)=561.3 * * *$ & & $\chi^{2}(19)=578.5^{* * *}$ \\
\hline Total & $23.7 \%$ & & $22.57 \%$ & & $24.56 \%$ & \\
\hline
\end{tabular}

*Statistically significant at the .10 level; ** at the .05 level; *** at the .01 level

ones $(20.60 \%)$. This same behavior was observed when comparing family and nonfamily firms.

Since analyzing the relationship between environmental and financial performance is one of the main interests of this paper, Table 3 presents a descriptive of the return on assets (ROA), including the results of six analyses of variance performed to study the differences in ROA of different types of firm. The results show that, while ROA is similar in family and non-family firms, there are significant differences according to environmental investment, firm size, age, sectorial activity and temporal variables. It can be seen how the ROA increases with the size of the firm and decreases with age, and firms with environmental investment have a higher ROA. This shows the need to consider control variables in the analyses performed with the aim of testing our hypotheses.

Finally, Table 3 shows the Pearson correlation matrix (Spearman) for dependent and control variables in the main analysis. The correlation between ROA and Environmental investment, Medium and Large size and Young age is positive, yet not 
Table 3 Descriptive analysis of ROA and Spearman's correlations between relevant variables

\begin{tabular}{|c|c|c|c|c|c|c|}
\hline & \multicolumn{3}{|c|}{ Descriptive: ROA } & \multicolumn{3}{|c|}{ Correlation matrix } \\
\hline & Mean & $\mathrm{SD}$ & Difference test & ROA & Family owned & $\begin{array}{l}\text { Environmen- } \\
\text { tal invest- } \\
\text { ment }\end{array}$ \\
\hline \multicolumn{7}{|l|}{ Family owned } \\
\hline Yes & 8.70 & 15.04 & $\mathrm{t}=1.00$ & -0.003 & 1 & \\
\hline No & 8.97 & 16.76 & & & & \\
\hline \multicolumn{7}{|c|}{ Environmental investment } \\
\hline Yes & 11.11 & 12.68 & $\mathrm{t}=-9.22 * * *$ & $0.116^{* * * *}$ & $-0.023 * * *$ & 1 \\
\hline No & 8.15 & 16.86 & & & & \\
\hline \multicolumn{7}{|l|}{ Size } \\
\hline Small (less than 50) & 8.10 & 17.69 & $\mathrm{~F}=16.74 * * *$ & $-0.089 * * *$ & $0.032 * * *$ & $-0.379 * * *$ \\
\hline Medium (50 to 249 ) & 9.41 & 14.19 & & $0.054 * * *$ & $0.050 * * *$ & $0.126 * * *$ \\
\hline Large (250 or more) & 10.08 & 13.81 & & $0.053 * * *$ & $-0.111 * * *$ & $0.361 * * *$ \\
\hline \multicolumn{7}{|l|}{ Age/experience } \\
\hline Young (less than 15) & 10.22 & 17.55 & $\mathrm{~F}=8.62 * * *$ & $0.037 * * *$ & $-0.077 * * *$ & $-0.030 * * *$ \\
\hline Mature (15 to 29 ) & 8.69 & 16.06 & & -0.012 & 0.003 & $-0.126^{* * *}$ \\
\hline Old (30 or more) & 8.54 & 15.40 & & $-0.014^{*}$ & $0.052 * * *$ & $0.147 * * *$ \\
\hline Temporal variables & & & $\mathrm{F}=18.01 * * *$ & & & \\
\hline Sectorial variables & & & $\mathrm{F}=15.28 * * *$ & & & \\
\hline Total & 8.85 & 16.02 & & & & \\
\hline
\end{tabular}

*Statistically significant at the .10 level; ** at the .05 level; *** at the .01 level

large $(0.116,0.054,0.053$ and 0.037 , respectively), which, according to the Spearman correlation, are significant values, thus highlighting the need to control for the effects of size and age. Besides, the correlation of ROA with Small size and Old age was negative and significant, as indicated by the Pearson (Spearman) correlations of -0.089 and -0.014 , respectively. Collinearity does not seem to be a problem given the small correlation observed between control variables and the fact that the highest variance inflation factor (VIF) is under 5 (including in the analysis of temporal and sectorial effects).

\subsection{Estimation results}

Table 4 shows the results related to the model presented in Equation [1]. Column (1) presents the environmental investment effect on ROA, one of the main objectives of this paper. Column (2) includes size and age effects as control variables. As further tests of robustness, column (3) includes temporal and sectorial effects in the list of control variables. Also for further testing of robustness, two sub-samples were generated. The first sub-sample was for family firms and the second for non-family firms. One of the advantages of the panel data methodology is that it makes it possible to control for different omitted effects that vary across firms and which affect 


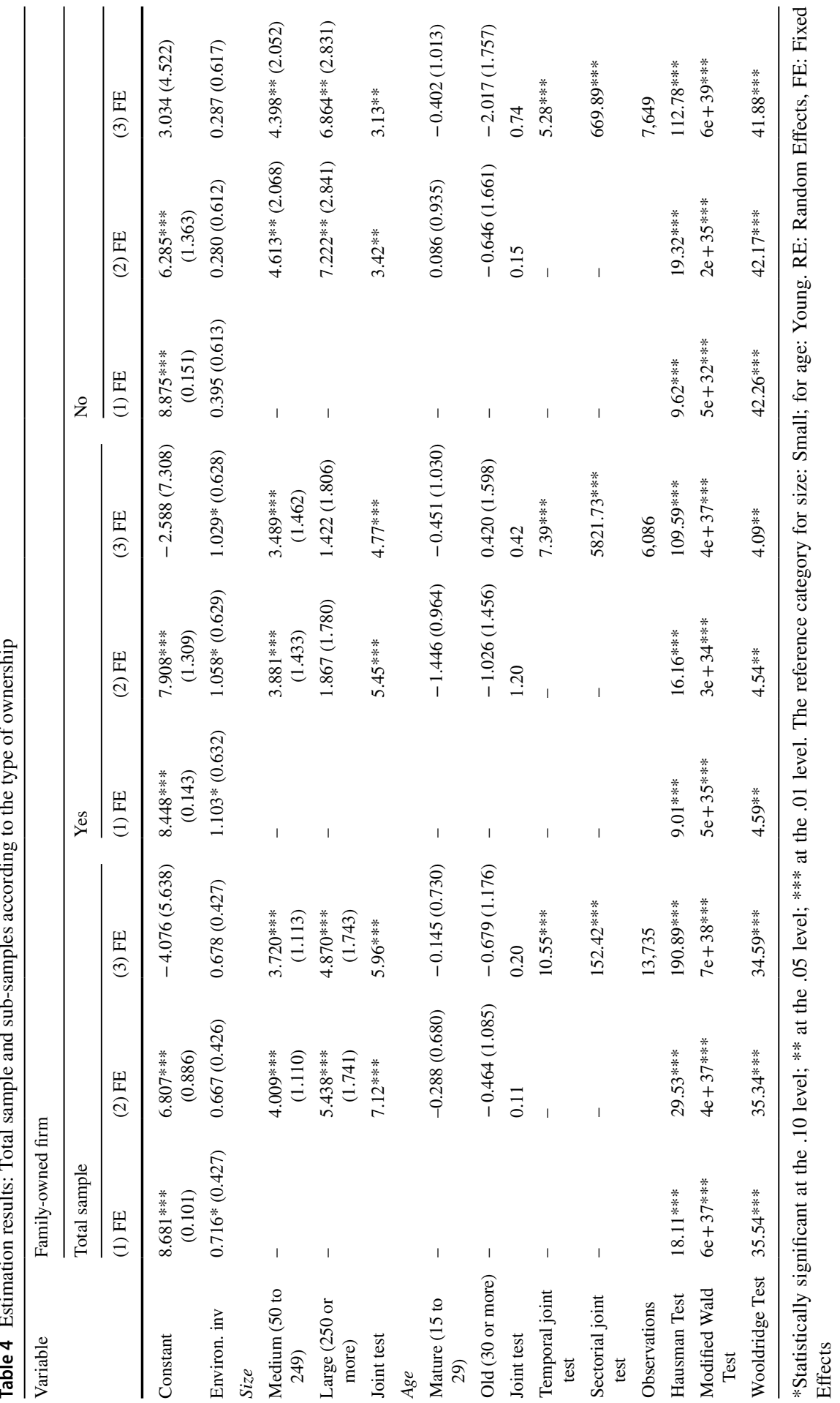


the variable to be explained; examples of these effects would be their know-how, their organizational culture or their skills. The Hausman specification test rejected the null hypothesis of random firm-specific effects in the specifications presented, so we focused on the results when the firms' effects were fixed.

In the total sample of Spanish manufacturing firms, environmental investment had a positive impact on financial performance $(0.716 ; \mathrm{p}<0.10)$, as can be seen in column (1). This estimation includes the correction of the (fixed) specific effects for each firm. But when the additional control variables were introduced in the regression analysis (columns 2 and 3) it was no longer significant. The robustness tests included fixed effects estimations for the sub-samples of family and non-family owned firms. For the sub-sample of family firms, we found a robust positive and significant coefficient $(1.029 ; \mathrm{p}<0.10$; column 3$)$, but not for the sub-sample of nonfamily firms $(0.287$; $p>0.10$; column 3$)$. Hypothesis 1 , then, is only partially supported, as investing in environmental protection has no significant effect on ROA in the sub-sample of non-family firms.

These results shed light on why the debate on the question "Does it pay to be green?" is still open and highlight the relevance of control and moderating variables in the empirical analyses aimed at answering this question. In this sense, some authors have previously attributed the heterogeneous empirical evidence offered by research in this line to the different selections of samples, variables or methodologies (Trumpp and Guenther 2017; Cañón-de-Francia and Garcés-Ayerbe 2019). Our results for Hypothesis 1 are consistent with this idea.

Regarding Hypothesis 2, which suggests that the profits derived from environmental investment are greater for family than for non-family firms, we mentioned earlier that the results of the regressions for both sub-samples showed that the impact of environmental investment on financial performance was significant in family firms, but not in non-family enterprises. In family firms, the positive effect of environmental investment on economic returns was maintained when control variables that correct for sectorial, temporal, size and age effects were included in the regression. In fact, the effect of environmental investment on economic profitability includes the correction of firm-specific effects, which have not been considered through these control variables. The results of our study therefore show the relevance of the type of ownership (family vs. non-family) as an aspect that generally moderates the relationship between environmental effort and financial result. These results support Hypothesis 2 and confirm with robust empirical evidence those previously obtained by Craig and Dibrell (2006) and Huang et al. (2009).

\section{Conclusions}

This paper is focused on studying the moderating effect of the family (or non-family) nature of the firm on the relationship between the firm's environmental and financial performance. The debate on the relationship between the two variables in the field of business management goes back decades. Hart and Ahuja (1996) posed the question "Does it pay to be green?", which gave rise to a large number of theoretical and empirical contributions. However, after a review of these contributions in the 
last few years authors like Alshehhi et al. (2018) or Cañón-de-Francia and GarcésAyerbe (2019) have pointed out that the debate is still open.

The answer to the original question is not simple, because the relationship between environmental performance and financial performance is complex. Therefore, over time, the debate has been redirected towards the question "When does it pay to be green?" (Orsato 2006; Ambec and Lanoie 2008; Dixon-Fowler et al. 2013; Ghisetti and Rennings 2014) and authors such as Endrikat et al. (2014) have suggested considering the existence of moderating variables that affect this relationship. This could explain the lack of consistency in the results of previous studies.

Grewatsch and Kleindienst (2015) proposed the different types of ownership (family versus non-family) as possible moderating variable of the relationship between environmental and financial performance. However, very few studies have paid attention to this issue. In our search we only found the studies by Craig and Dibrell (2006) and Huang et al. (2014).

Hence, this study aims to contribute to the literature about the relationship between a firm's environmental protection investments and its financial performance, by incorporating into the analysis the moderating effect of the family (or non-family) nature of the firm. By integrating the theoretical framework of the SEW perspective into the NRBV, the study provides empirical evidence from panel data on Spanish manufacturing firms in the period 2009-2016.

The initial results, considering the sample overall, show that the impact of environmental investment on financial performance is positive. This is consistent with the arguments of the NRBV, supported by numerous previous studies (for example, Xepapadeas and Zeeuw 1999; Bénabou and Tirole 2010; Grekova et al. 2013 or Testa et al. 2018). These contributions maintain that competitive advantages derived from environmental investment (associated with improving corporate image, stakeholder relationships, operative efficiency, product quality or market share, among others) led to better financial performance by firms.

Yet, the integration of the SEW perspective into the NRBV, in order to incorporate the possible moderating effect of type of ownership (family or non-family firm) into the analysis, results in a significant clarification of the initial results. The SEW perspective maintains that family firms have distinctive features that could favour a win-win situation between environmental and financial performance (Craig and Dibrell 2006; Neubaum et al. 2012; Huang et al. 2014). And the results show robust empirical evidence that, indeed, the win-win situation is only maintained in the subsample of family firms, while this is not the case in the sub-sample of non-family firms. That is, while a priori the relationship between environmental and financial performance appears to be positive, when we perform a deeper analysis incorporating the family versus non-family nature as a moderating variable of the relationship, the results show that this is only the case for family firms. Introducing time, sector, size and age control variables into our empirical analyses, together with the application of the panel data methodology, provides empirical evidence that, in general, in the period analyzed family firms are more successful in making a return on their environmental investments than non-family firms. We draw the conclusion, then, that the status of a family firm is one of the business factors that facilitate the possibility of environmental protection projects being translated into a win-win situation. 
Our results are consistent with the scarce research previously conducted in this line by Craig and Dibrell (2006) and Huang et al. (2014), which shows, both theoretically and empirically, that proactive environmental practices are economically more profitable in family firms.

The justification for these results is likely to be linked to the main characteristics that authors such as Gómez-Mejía et al. (2007), Neubaum et al. (2012) or Sageder et al. (2018) have established as distinctive of family firms. Firstly, family firms, guided by the desire for generational continuity, manage their resources and make their strategic decisions with a long-term vision that conditions the selection of their investment projects. Secondly, they place high value on the reputation and image of the brand, which is inevitably associated with the name of the family that owns it, and so they make a special effort to take advantage of its environmental protection strategies. Thirdly, family firms enjoy greater trust and involvement of employees and other stakeholders, which facilitates the implementation and use of investment projects. In sum, the environmental investment projects might possibly be better designed and/or implemented in family firms, thereby enabling a superior improvement in financial performance.

The conclusions of this research contribute to the knowledge of a condition under which we can expect a positive economic return from environmental investments, the family nature (or not) of the firm. Furthermore, they provide theoretical and empirical support to a specific research question about which there is scarcely any previous literature: "Does it pay to be green in family firms more than in non-family firms?". They are of interest to both academics and practitioners in the field of corporate management. The main theoretical contribution for future research lies in the integration of two perspectives or approaches: the SEW perspective and the NRBV. This allows us to complement or enrich the analysis and to improve the understanding of the complex relationship between the company's environmental performance and its financial performance. Endrikat et al. (2014) also adopted a hybrid theoretical framework to address the apparent lack of consensus among the results of hundreds of previous studies. In addition, the work also has valuable practical implications for family firms, given that due to their distinctive characteristics they seem to have more resources or capabilities to make their environmental investments profitable. This means that family firms would be more likely to achieve win-win situations between environmental and financial performance (Craig and Dibrell 2006; Huang et al. 2014). In short, environmental investments can not only contribute to increasing the socioemotional wealth of family businesses, but can also become a source of competitive advantage compared to non-family businesses.

Open Access This article is licensed under a Creative Commons Attribution 4.0 International License, which permits use, sharing, adaptation, distribution and reproduction in any medium or format, as long as you give appropriate credit to the original author(s) and the source, provide a link to the Creative Commons licence, and indicate if changes were made. The images or other third party material in this article are included in the article's Creative Commons licence, unless indicated otherwise in a credit line to the material. If material is not included in the article's Creative Commons licence and your intended use is not permitted by statutory regulation or exceeds the permitted use, you will need to obtain permission 
directly from the copyright holder. To view a copy of this licence, visit http://creativecommons.org/licen ses/by/4.0/.

\section{References}

Aguilera-Caracuel J, Ortiz-de-Mandojana N (2013) Green innovation and financial performance: An institutional approach. Organ Environ. https://doi.org/10.1177/1086026613507931

Albertini E (2013) Does environmental management improve financial performance? A meta-analytical review. Organ Environ. https://doi.org/10.1177/1086026613510301

Alshehhi A, Nobanee H, Khare N (2018) The impact of sustainability practices on corporate financial performance: Literature trends and future research potential. Sustainability. https://doi.org/10.3390/ su 10020494

Ambec S, Lanoie P (2008) Does it pay to be green? A systematic overview. Acad Manag Perspect. https://doi.org/10.5465/amp.2008.35590353

Aragón-Correa JA, Sharma S (2003) A contingent resource-based view of proactive corporate environmental strategy. Acad Manag Rev. https://doi.org/10.5465/amr.2003.8925233

Aragón-Correa JA, Hurtado-Torres N, Sharma S, García-Morales VJ (2008) Environmental strategy and performance in small firms: A resource-based perspective. J Environ Manage. https://doi.org/10. 1016/j.jenvman.2006.11.022

Arregle JL, Hitt MA, Sirmon DG, Very P (2007) The Development of Organizational Social Capital: Attributes of Family Firms. J Manage Stud. https://doi.org/10.1111/j.1467-6486.2007.00665.x

Azoury A, Daou L, Sleiaty F (2013) Employee engagement in family and non-family firms. Int Strateg Manag Rev. https://doi.org/10.1016/j.ism.2013.08.002

Baah C, Jin Z, Tang L (2020) Organizational and regulatory stakeholder pressures friends or foes to green logistics practices and financial performance: investigating corporate reputation as a missing link. J Clean Prod. https://doi.org/10.1016/j.jclepro.2019.119125

Bansal P (2005) Evolving sustainably: a longitudinal study of corporate sustainable development. Strateg Manag J. https://doi.org/10.1002/smj.441

Barney JB (1991) Firm resources and sustained competitive advantage. J Manag. https://doi.org/10.1177/ 014920639101700108

Basco R (2017) "Where do you want to take your family firm?" A theoretical and empirical exploratory study of family business goals. Bus Res Q. https://doi.org/10.1016/j.brq.2016.07.001

Bénabou R, Tirole J (2010) Individual and corporate social responsibility. Economica. https://doi.org/10. 1111/j.1468-0335.2009.00843.x

Berrone P, Cruz C, Gómez-Mejía LR, Larraza-Kintana M (2010) Socioemotional wealth and corporate responses to institutional pressures: do family-controlled firms pollute less? Adm Sci Q. https://doi. org/10.2189/asqu.2010.55.1.82

Berrone P, Fosfuri A, Gelabert L, Gómez-Mejía LR (2013) Necessity as the mother of 'green' inventions: institutional pressures and environmental innovations. Strateg Manag J. https://doi.org/10.1002/smj. 2041

Bostian M, Färe R, Grosskopf S, Lundgren T (2016) Environmental investment and firm performance: a network approach. Energy Economics. https://doi.org/10.1016/j.eneco.2016.05.013

Brekke KA, Nyborg K (2008) Attracting responsible employees: green production as labor market screening. Resour Energy Econ. https://doi.org/10.1016/j.reseneeco.2008.05.001

Bruton GD, Ahlstrom D, Wan JC (2003) Turnaround in East Asian firms: evidence from ethnic overseas Chinese communities. Strateg Manag J. https://doi.org/10.1002/smj.312

Cañón-de-Francia J, Garcés-Ayerbe C (2019) Factors and contingencies for the "it Pays to Be green hypothesis". The European Union's emissions trading system (EU ETS) and financial crisis as contexts. Int J Environ Res Public Health. https://doi.org/10.3390/ijerph16162988

Christmann P (2000) Effects of "best practices" of environmental management on cost advantage: the role of complementary assets. Acad Manag J. https://doi.org/10.5465/1556360

Collins CJ, Smith KG (2006) Knowledge exchange and combination: the role of human resource practices in the performance of high-technology firms. Acad Manag J. https://doi.org/10.5465/amj.2006. 21794671 
Corona J, Téllez-Roca J (2011) El protocolo familiar en empresa familiar: aspectos jurídicos y económicos. In Corona J (ed) Empresa familiar: aspectos jurídicos y económicos pp 397-421. Ediciones, Barcelona, Spain

Craig J, Dibrell C (2006) The natural environment, innovation and firm performance: a comparative study. Fam Bus Rev. https://doi.org/10.1111/j.1741-6248.2006.00075.x

Debicki BJ, Van de Graaff Randolph R, Sobczak M (2017) Socioemotional wealth and family firm performance: a stakeholder approach. J Manag Issues. https://www.jstor.org/stable/45176535

Dierickx I, Cool K (1989) Asset stock accumulation and the sustainability of competitive advantage. Manage Sci. https://doi.org/10.1287/mnsc.35.12.1514

Dixon-Fowler HR, Slater DJ, Johnson JL, Ellstrand AE, Romi AM (2013) Beyond "does it pay to be green?" A meta-analysis of moderators of the CEP-CFP relationship. J Bus Ethics. https://doi.org/ $10.1007 / \mathrm{s} 10551-012-1268-8$

Eddleston KA, Kellermanns FW (2007) Destructive and productive family relationships: a stewardship theory perspective. J Bus Ventur. https://doi.org/10.1016/j.jbusvent.2006.06.004

Endrikat J, Guenther E, Hoppe H (2014) Making sense of conflicting empirical findings: a meta-analytic review of the relationship between corporate environmental and financial performance. Eur Manag J. https://doi.org/10.1016/j.emj.2013.12.004

Filbeck G, Gorman RF (2004) The relationship between the environmental and financial performance of public utilities. Environ Resource Econ. https://doi.org/10.1023/B:EARE.0000044602.86367.ff

Garcés-Ayerbe C, Cañón-de-Francia J (2017) The relevance of complementarities in the study of the economic consequences of environmental proactivity: analysis of the moderating effect of innovation efforts. Ecol Econ. https://doi.org/10.1016/j.ecolecon.2017.06.022

Gast J, Filser M, Rigtering JPC, Harms R, Kraus S, Chang ML (2018) Socioemotional wealth and innovativeness in small- and medium-sized family enterprises: a configuration approach. J Small Bus Manage. https://doi.org/10.1111/jsbm.12389

Ghisetti C, Rennings K (2014) Environmental innovations and profitability: how does it pay to be green? An empirical analysis on the German innovation survey. J Clean Prod. https://doi.org/10.1016/j. jclepro.2014.03.097

Gilley KM, Worrell DL, Davidson WN III, El-Jelly A, (2000) Corporate environmental initiatives and anticipated firm performance: the differential effects of process-driven versus product-driven greening initiatives. J Manag. https://doi.org/10.1177/014920630002600607

Gómez-Mejía LR, Haynes KT, Núñez-Nickel M, Jacobson KJ, Moyano-Fuentes J (2007) Socioemotional wealth and business risks in family-controlled firms: evidence from Spanish olive oil mills. Adm Sci Q. https://doi.org/10.2189/asqu.52.1.106

González-Benito J, González-Benito O (2005) Environmental proactivity and business performance: an empirical analysis. OMEGA. https://doi.org/10.1016/j.omega.2004.03.002

Grekova K, Bremmers HJ, Trienekens JH, Kemp RGM, Omta SWF (2013) The mediating role of environmental innovation in the relationship between environmental management and firm performance in a multi-stakeholder environment. J Chain Netw Sci. https://doi.org/10.3920/JCNS2013.1003

Grewatsch S, Kleindienst I (2015) When does it pay to be good? Moderators and mediators in the corporate sustainability-corporate financial performance relationship: a critical review. J Bus Ethics. https://doi.org/10.1007/s10551-015-2852-5

Habbershon TG, Pistrui J (2002) Enterprising families' domain: family-influenced ownership groups in pursuit of transgenerational wealth. Fam Bus Rev. https://doi.org/10.1111/j.1741-6248.2002. 00223.x

Habbershon TG, Williams M, MacMillan IC (2003) A unified systems perspective of family firm performance. J Bus Ventur. https://doi.org/10.1016/S0883-9026(03)00053-3

Hart SL (1995) A natural resource-based view of the firm. Acad Manag Rev. https://doi.org/10.5465/amr. 1995.9512280033

Hart SL, Ahuja G (1996) Does it pay to be green? An empirical examination of the relationship between emission reduction and firm performance. Bus Strategy Environ. https://doi.org/10.1002/(SICI) 1099-0836(199603)5:1<30::AID-BSE38>3.0.CO;2-Q

Hart SL, Dowell G (2011) Invited editorial: a natural-resource-based view of the firm: fifteen years after. J Manag. https://doi.org/10.1177/0149206310390219

Hart SL, Milstein MB (2003) Creating sustainable value. Acad Manag Perspect. https://doi.org/10.5465/ ame.2003.10025194

Huang YC, Ding HB, Kao MR (2009) Salient stakeholder voices: Family business and green innovation adoption. J Manag Org. https://doi.org/10.5172/jmo.2009.15.3.309 
Huang YC, Wong YJ, Yang ML (2014) Proactive environmental management and performance by a controlling family. Manag Res Rev. https://doi.org/10.1108/MRR-09-2012-0196

Iranmanesh M, Fayezi S, Hanim S, Hyun SS (2019) Drivers and outcomes of eco-design initiatives: a cross-country study of Malaysia and Australia. RMS. https://doi.org/10.1007/s11846-018-0282-3

Jaffe AB, Peterson SR, Portney PR, Stavins RN (1995) Environmental regulation and the competitiveness of US manufacturing: what does the evidence tell us? J Econ Literat 33(1):132-163

Kellermanns FW, Eddleston KA, Sarathy R, Murphy F (2012) Innovativeness in family firms: a family influence perspective. Small Bus Econ. https://doi.org/10.1007/s11187-010-9268-5

Klassen RD, McLaughlin CP (1996) The impact of environmental management on firm performance. Manage Sci. https://doi.org/10.1287/mnsc.42.8.1199

Kushwaha GS, Sharma NK (2016) Green initiatives: a step towards sustainable development and firm's performance in the automobile industry. J Clean Prod. https://doi.org/10.1016/j.jclepro. 2015.07.072

Le Breton-Miller I, Miller D (2006) Why do some family businesses out-compete? Governance, long-term orientations, and sustainable capability. Entrep Theory Pract. https://doi.org/10. 1111/j.1540-6520.2006.00147.x

Li S, Ngniatedema T, Chen F (2017) Understanding the impact of green initiatives and green performance on financial performance in the US. Bus Strateg Environ. https://doi.org/10.1002/bse. 1948

López-Cózar-Navarro C, Priede-Bergamini T, Benito-Hernández S (2016) The nexus between size and external business advice in the family firm. Acad. Rev. Latinoam. de Adm. https://doi.org/10.1108/ ARLA-01-2016-0010

Lucas MT, Noordewier TG (2016) Environmental management practices and firm financial performance: the moderating effect of industry pollution-related factors. Int JProd Econ. https://doi.org/10.1016/j. ijpe.2016.02.003

Lucato WC, Costa EM, De Oliveira Neto GC (2017) The environmental performance of SMEs in the Brazilian textile industry and the relationship with their financial performance. J Environ Manage. https://doi.org/10.1016/j.jenvman.2017.06.028

Makower J (1993) The E Factor: the bottom line approach to environmental responsibility. Tilden Press [Random House], New York. https://doi.org/10.1177/027046769501500427

Melay I, Kraus S (2012) Green entrepreneurship: definitions of related concepts. Int J Strateg Manag $12: 1-12$

Menguc B, Ozanne LK (2005) Challenges of the "green imperative": a natural resource-based approach to the environmental orientation-business performance relationship. J Bus Res. https:// doi.org/10.1016/j.jbusres.2003.09.002

Miroshnychenko I, Barontini R, Testa F (2017) Green practices and financial performance: a global outlook. J Clean Prod. https://doi.org/10.1016/j.jclepro.2017.01.058

Mohr A, Puck J (2013) Revisiting the trust-performance link in strategic alliances. Manag Int Rev. https://doi.org/10.1007/s11575-012-0145-0

Molina-Azorín JF, Claver-Cortés E, López-Gamero MD, Tarí JJ (2009) Green management and financial performance: a literature review. Manag Decis. https://doi.org/10.1108/00251740910978313

Nakamura E (2011) Does environmental investment really contribute to firm performance? An empirical analysis using Japanese firms. Eurasian Bus Rev. https://doi.org/10.14208/BF03353800

Nakao Y, Amano A, Matsumura K, Genba K, Nakano M (2007) Relationship between environmental performance and financial performance: an empirical analysis of Japanese corporations. Bus Strateg Environ. https://doi.org/10.1002/bse.476

Neubaum DO, Dibrell C, Craig JB (2012) Balancing natural environmental concerns of internal and external stakeholders in family and non-family businesses. J Fam Bus Strat. https://doi.org/10. 1016/j.jfbs.2012.01.003

Navarro CLC, Bergamini TP, Hernández SB (2013) Influencia de la deuda en la estrategia de exportación de la empresa familiar. Revista de Empresa Familiar.. https://abacus.universidadeuropea.es/ bitstream/handle/11268/331/1210.pdf?sequence=1

Orsato RJ (2006) Competitive environmental strategies: when does it pay to be green? Calif Manage Rev. https://doi.org/10.2307/41166341

Pekovic S, Vogt S (2020) The fit between corporate social responsibility and corporate governance: the impact on a firm's financial performance. RMS. https://doi.org/10.1007/s11846-020-00389-X

Porter M (1991) America's green strategy. Sci Am 264(4):168

Porter M, Van der Linde C (1995) Green and competitive. Harv Bus Rev 73(5):120-134 
Preston LE, O'Bannon DP (1997) The corporate social-financial performance relationship: a typology and analysis. Bus Soc. https://doi.org/10.1177/000765039703600406

Ramanathan R (2018) Understanding complexity: the curvilinear relationship between environmental performance and firm performance. J Bus Ethics. https://doi.org/10.1007/s10551-016-3088-8

Ramírez Y, Dieguez-Soto J, Manzaneque M (2020) How does intellectual capital efficiency affect firm performance? The moderating role of family management. Int $\mathrm{J}$ Prod Performance Manag. https://doi.org/10.1108/IJPPM-03-2019-0119

Ramírez-Alesón M, Fernández-Olmos M (2019) Intermediate imports and innovation performance: do family firms benefit more? Eur J Innov Manag. https://doi.org/10.1108/EJIM-05-2019-0116

Rivera-Torres P, Garcés-Ayerbe C, Scarpellini S, Valero-Gil J (2015) Pro-environmental change and short- to mid-term economic performance: the mediating effect of organisational design change. Organ Environ. https://doi.org/10.1177/1086026615603867

Rumelt RP (1984) Towards a strategic theory of the firm. In: Lamb RB (ed) Competitive strategic management. Prentice Hall, Englewood Cliffs, NJ, pp 556-571

Russo MV, Fouts PA (1997) A resource-based perspective on corporate environmental performance and profitability. Acad Manag J. https://doi.org/10.5465/257052

Sageder M, Mitter C, Feldbauer-Durstmüller B (2018) Image and reputation of family firms: a systematic literature review of the state of research. RMS. https://doi.org/10.1007/s11846-016-0216-X

Sarkis J, Cordeiro JJ (2001) An empirical evaluation of environmental efficiencies and firm performance: pollution prevention versus end-of-pipe practice. Eur J Oper Res. https://doi.org/10.1016/ S0377-2217(00)00306-4

Sharma P, Irving PG (2005) Four bases of family business successor commitment: antecedents and consequences. Entrep Theory Pract. https://doi.org/10.1111/j.1540-6520.2005.00067.x

Sharma P, Manikutty S (2005) Strategic divestments in family firms: role of family structure and community culture. Entrep Theory Pract. https://doi.org/10.1111/j.1540-6520.2005.00084.x

Sharma S, Vredenburg H (1998) Proactive corporate environmental strategy and the development of competitively valuable organizational capabilities. Strateg Manag J. https://doi.org/10.1002/ (SICI)1097-0266(199808)19:8\%3c729::AID-SMJ967\%3e3.0.CO;2-4

Song H, Zhao C, Zeng J (2017) Can environmental management improve financial performance: an empirical study of A-shares listed companies in China. J Clean Prod. https://doi.org/10.1016/j. jclepro.2016.09.105

Sueyoshi T, Goto M (2010) Measurement of a linkage among environmental, operational, and financial performance in Japanese manufacturing firms: a use of Data Envelopment Analysis with strong complementary slackness condition. Eur J Oper Res. https://doi.org/10.1016/j.ejor.2010. 07.024

Testa F, Boiral O, Iraldo F (2018) Internalization of environmental practices and institutional complexity: can stakeholders pressures encourage greenwashing? J Bus Ethics. https://doi.org/10. 1007/s10551-015-2960-2

Trumpp C, Guenther T (2017) Too Little or too much? Exploring U-shaped relationships between corporate environmental performance and corporate financial performance. Bus Strateg Environ. https://doi.org/10.1002/bse.1900

Uhlaner LM, Van Goor-Balk H, Masurel E (2004) Family business and corporate social responsibility in a sample of Dutch firms. J Small Bus Enterp Dev. https://doi.org/10.1108/146260004105371 28

Vachon S, Klassen RD (2008) Environmental management and manufacturing performance: the role of collaboration in the supply chain. Int J Prod Econ. https://doi.org/10.1016/j.ijpe.2006.11.030

Venkatraman S, Nayak RR (2015) Corporate sustainability: An IS approach for integrating triple bottom line elements. Social Responsibility Journal. https://doi.org/10.1108/SRJ-11-2013-0136

Walley N, Whitehead B (1994) It's not easy being green. Harv Bus Rev 72(3):46-52

Watson K, Klingenberg B, Polito T, Geurts TG (2004) Impact of environmental management system implementation on financial performance: a comparison of two corporate strategies. Manag Environ Qual. https://doi.org/10.1108/14777830410560700

Xepapadeas A, Zeeuw A (1999) Environmental policy and competitiveness: the porter hypothesis and the composition of capital. J Environ Econ Manag. https://doi.org/10.1006/jeem.1998.1061

Xi JM, Kraus S, Filser M, Kellermanns FW (2015) Mapping the field of family business research: past trends and future directions. Int Entrep Manag J. https://doi.org/10.1007/s11365-013-0286-Z

Yu M, Zhao R (2015) Sustainability and firm valuation: an international investigation. Int J Account Inf Manag. https://doi.org/10.1108/IJAIM-07-2014-0050 
Zellweger TM, Nason RS (2008) A stakeholder perspective on family firm performance. Fam Bus Rev. https://doi.org/10.1177/08944865080210030103

Zellweger TM, Nason RS, Nordqvist M, Brush, CG (2013) Why do family firms strive for nonfinancial goals? An organizational identity perspective. Entrep Theory Pr. https://doi.org/10.1111/j.15406520.2011.00466.x

Publisher's Note Springer Nature remains neutral with regard to jurisdictional claims in published maps and institutional affiliations. 